\title{
Copyright and Free Speech: Constitutional Limitations on the Protection of Expression
}

\author{
Robert C. Denicola $\uparrow$
}

The excitement attending the passage of the new Copyright Act ${ }^{1}$ must be apparent even to the most casual observer of intellectual property law. It readily can be appreciated by any who have had to confront the copyright problems created by modern photocopyers, computers, or cable television, armed only with a 1909 statute still struggling mightily to assimilate the player piano roll. ${ }^{2}$ The Copyright Act of $1909^{3}$ did not succumb without a struggle. It survived for more than two decades after the revision effort had begun, ${ }^{4}$ and the renovations remaim incomplete. ${ }^{5}$ Nevertheless, the courts will soon be searching the seventy-odd sections of the new legislation for answers to a host of foreseen and, inevitably, unforeseen problems. Legal scholars, unencumbered by notions of cases or controversies, are already busily surveying the contours of the new landscape. ${ }^{6}$ Yet, even as the commentators focus on the intricacies of the congressional handiwork, an issue of constitutional dimensions is slowly crystallizing in a series of judicial decisions.

A publisher who lias printed abstracts of copyrighted financial reports defends against a charge of copyright infringement by arguing that the abstracts are financial news coverage protected by the first

$\dagger$ Associate Professor of Law, University of Nebraska. B.S.E. 1971, Princeton University; J.D. 1974, LL.M. 1976, Harvard Law School.

l. Copyright Act of 1976, Pub. L. No. 94-553, 90 Stat. 2541 (codified at 17 U.S.C. app. $\S \S 101-810(1976))$.

2. See White-Smith Music Co. v. Apollo Co., 209 U.S. 1 (1908).

3. Act of March 4, 1909, ch. 320,35 Stat. 1075 (current version at 17 U.S.C. app. $\$ \S 101-810$ (1976)).

4. For a summary of the legislative history of the new Act, see H.R. REP. No. 94-1476, 94th Cong., 2d Sess. 47-50 (1976) [hereinafter cited as H.R. Rep. No. 94-1476]; S. REP. No. 94-473, 94th Cong., 1st Sess. 47-50 (1975) [hereinafter cited as S. REp. No. 94-473].

5. See Ringer, The Unfinished Business of Copyright Revision, 24 UCLA L. Rev. 951 (1977).

6. See, e.g., Copyright Symposium (pts. 1-2), 22 N.Y.L. ScH. L. Rev. 193, 471 (1976-1977); New Copyright Act, 6 AM. PAT. L.A.Q.J. 10 (1978); Symposium: The Copyright Act of 1976, 24 UCLA L. REV. 951 (1977). 
amendment guarantees of free speech and free press. ${ }^{7}$ A lawyer who has written a book analyzing the espionage trial of Julius and Ethel Rosenberg argues that the inclusion of portions of twenty-eight copyrighted letters written by the Rosenbergs should not be considered an infringement because of the public interest in the free dissemmation of inforination. ${ }^{8}$ A federal court in Florida is persuaded that the first amendment prohibits an order enjoining a newspaper from depicting the cover of a competing copyrighted television guide in a coinparative advertising campaign, ${ }^{9}$ while the McDonald's Corporation, pressing imexorably toward its twenty-sixth billion hamburger, attempts to convince the United States Court of Appeals for the Nimth Circuit that the broad scope of protection given to copyrighted television characters impimges on its freedoin of speech. ${ }^{10}$ These cases, and others like them, have coinpelled judicial consideration of the potential conflict between copyright law and the first amendment guarantees of free speech and free press.

This Article will attempt to structure a workable accoininodation between the first amendinent and the property rights in "origmal works of authorship" granted by federal copyright law. The internal rules of copyright doctrine first will be examined to see how they themselves operate to avoid potential confrontation with first amendment values. Then, to the extent that possible conflict remains, the scope of the external first amendment privilege necessary to insure the constitutionality of the system will be considered. First amendment challenges to the rights of copyright owners are becouning inore frequent. The task is to determine which of these challenges safely may be cast aside, and which, if any, are entitled to constitutional recognition.

\section{The Confrontation}

Even a cursory exaunination of the origims of copyright law reveals the potential conflict between property rights in intellectual creations and freedom of expression. In its earliest stages, the copyright system was a device to enable the English Crown to control the output of the newly invented printing press. Initially, the control took the forin of royal grants for the exclusive printing of particular books. Later, a

7. Wainwright Sec. Inc. v. Wall St. Transcript Corp., 558 F.2d 91 (2d Cir. 1977), cert. denied, 434 U.S. 1014 (1978).

8. Meeropol v. Nizer, 560 F.2d 1061 (2d Cir. 1977), cert. denied, 434 U.S. 1013 (1978).

9. Triangle Publications, Inc. v. Knight-Ridder Newspapers, Inc., 445 F. Supp. 875 (S.D. Fla. 1978).

10. Sid \& Marty Krofft Television Prods., Inc. v. McDonald's Corp., 562 F.2d 1157 (9th Cir. 1977). 
printing monopoly was granted to the Stationers' Company, a trade association of favored printers. ${ }^{11}$ Although direct attempts at censorship had ceased by 1709 when the first modern copyright statute was enacted, ${ }^{12}$ the tension between copyright and free speech still persists.

The Umited States Constitution grants to Congress the "Power to Promote the Progress of Science and useful Arts, by securing for Limited Times to Authors and Inventors the exclusive Right to their respective Writings and Discoveries." 13 The Supreme Court has said that the "economic philosophy behind the clause empowering Congress to grant patents and copyrights is the conviction that encouragement of mdividual effort by personal gam is the best way to advance public welfare through the talents of authors and inventors im 'Science and useful Arts." 14 The copyright law provides this encouragement by granting a right to exclude others from certain uses of the copyrighted work. Section 102 of the New Act extends federal copyright protection to "original works of authorship fixed in any tangible medium of expression."15 Section 106 gives the copyright owner the exclusive right to reproduce the work, prepare derivative works, distribute copies, and perforn or display the work in public. ${ }^{16}$

In contrast, the first amendment provides that "Congress shall make no law . . . abridging the freedom of speech, or of the press." The Court repeatedly has stated that freedom of speech and freedom of the press necessarily protect the right of the public both to speak and to receive inforination. ${ }^{17}$ The commitment to an ideal of freedom of

11. See B. Kaplan, AN Unhurried View of Copyright 2-6 (1966).

12. Act for the Encouragement of Learning, 1709, 8 Anne, c. 19.

13. U.S. Const. art. I, $\S 8$, cl. 8.

14. Mazer v. Stein, 347 U.S. 201, 219 (1954).

15. To illustrate the range of works eligible for protection, the section specifically lists literary, musical, and dramatic works; pantomimes and choreographic works; pictorial, graphic, and sculptural works; motion pictures and other audiovisual works, and sound recordings. 17 U.S.C. app. $\$ 102$ (a) (1976). The statutory list is "illustrative and not limitative." H.R. REP. No. 94-1476, supra note 4 , at 53 .

16. 17 U.S.C. app. 106 (1976). The entire section reads:

Subject to sections 107 through 118, the owner of copyright under this title has the exclusive rights to do and to authorize any of the following:

(1) to reproduce the copyrighted work in copies or phonorecords;

(2) to prepare derivative works based upon the copyrighted work;

(3) to distribute copies or phonorecords of the copyrighted work to the public by sale or other transfer of ownership, or by rental, lease, or lending;

(4) in the case of literary, musical, dramatic, and choreographic works, pantomimes, and motion pictures and other audiovisual works, to perform the copyrighted work pubhicly; and

(5) in the case of literary, inusical, dramatic, and choreographic works, pantomimes, and pictorial, graphic, or sculptural works, including the individual images of a motion picture or other audiovisual work, to display the copyrighted work publicly.

17. See, e.g., Kleimdienst v. Mandel, 408 U.S. 753, 762-63 (1972); Red Lion Broadcasting Co. v. FCC, 395 U.S. 367, 390 (1969); Stanley v. Georgia, 394 U.S. 557, 564 (1969); Martin v. City of Struthers, 319 U.S. 141, 143 (1943). 
speech reflects a series of political and social value judgments. ${ }^{18}$ The Supreme Court has rationalized freedom of speech as a means of "preserv[img] an uninhibited marketplace of ideas in which truth will ultimately prevail." 19 Freedom of speech can also serve to strengthen the fabric of society itself. Free speech allows individuals to gather the information necessary to make informed decisions as part of the democratic process. ${ }^{20}$ It can act as a stabilizing force in society in that it channels potentially disruptive energy into a inore useful public dialogue and provides a feeling of individual participation that enhances acceptance of the governing consensus. ${ }^{21}$ Finally, freedoin of speech may also be justified as a goal in itself. In the words of Justice Brandeis: "Those who won our independence believed that the final end of the State was to make men free to develop their faculties . . .."22 Limitations on the freedon to speak and hear interfere with the ability of individuals to achieve their full potential, and thus may be viewed as an unacceptable exercise of governmental authority. ${ }^{23}$

These first amendment values have been incorporated into our legal system from its inception. The problem thus is to determine whether a statutory scheine that recognizes property rights in "origmal works of authorship" can operate in a fashion consistent with these fundainental values. In a series of cases presenting an analogous dilemma, the Supreine Court has been called on to reconcile the first aunendinent with private law doctrimes touching on individual expression. Its approach seems to be to ask whether the activity that is threatened witl liability is of a sort that furthers the interests underlying the first amendment. When the recognition of private rights would prohibit or curtail forms of communication that advance these interests, the private rights inust yield to the constitutional interests.

In New York Times Co. v. Sullivan, ${ }^{24}$ for example, the Court considered the relationship between freedoin of speech and state libel law. After reviewing the basic primciples behind the commitment to free speech, the Court held that the first amendment precluded recovery by public officials for defamatory statements relating to their official conduct unless the stateinents were made with knowledge of their falsity or in reckless disregard of the truth. ${ }^{25}$ Presuinably, defamatory statements

18. See Emerson, Toward a General Theory of the First Amendment, 72 YALE L.J. 877, 87886 (1963).

19. Red Lion Broadcasting Co. v. FCC, 395 U.S. 367, 390 (1969).

20. See Meiklejohn, The First Amendment Is an Absolute, 1961 SuP. CT. REv. 245, 255-57.

21. Whitney v. California, 274 U.S. 357, 375 (1927) (Brandeis, J., concurring).

22. Id.

23. Emerson, supra note 18 , at $879-81$.

24. 376 U.S. 254 (1964).

25. Id. at $279-80$. 
made with knowledge of their falsity were not included within the protective sphere of the first amendment because such stateinents do not further the values underlying the ideal of free speech. ${ }^{26}$ In Time, Inc. $v$. Hill, ${ }^{27}$ the Court applied the Sullivan limitations on recovery to a suit brought under the New York right of privacy statute for false reports of matters of public interest. Such reports, unless made with knowledge of falsity or in reckless disregard of the truth, ${ }^{28}$ are constitutionally insulated from the threat of legal sanction.

New York Times and Time both were concerned with the constitutional limits imposed by the first amendment upon legal doctrines regulating forms of expression that intrude upon personal interests. In the copyright sphere, the task is to reach an accommodation between the first amendment and property interests in forms of expression. The Supreme Court recently upheld against first amendment challenge a cause of action based on an analogous property interest in Zacchini $v$. Scripps-Howard Broadcasting Co. ${ }^{29}$ The defendant in that case broadcast a fifteen second film showing an entire performance of plaintiff's "human cannonball" act on the eleven o'clock news. Zacchini instituted an action for damages alleging that the defendant had unlawfully appropriated his professional property. ${ }^{30}$ The Supreme Court of Ohio treated the claim as one founded on the right of publicity, notimg that "the fundamental wrong is the appropriation for one's self of the benefits of another's name, likeness, or identity." 31 It nonetheless denied recovery, holding that the first amendment as interpreted in New York Times and Time gave the television station a constitutional privilege to report on matters of legitimate public interest. ${ }^{32}$ The question to be resolved on appeal to the United States Supreme Court thus was whether the guarantees of free speech and free press immunized the defendant from potential hability arising from the invasion of plaintiff's proprietary right.

In determining whether recogmition of a property right im the pub-

26. See Garrison v. Louisiana, 379 U.S. 64, 75 (1964).

27. 385 U.S. 374 (1967).

28. Id. at 387-88.

29. 433 U.S. 562 (1977).

30. Id. at 564 .

31. 47 Ohio St. 2d 224, 229-30, 351 N.E.2d 454, 458 (1976), rev'd 433 U.S. 562 (1977). The right of publicity historically las been viewed as a segment of the general law of privacy. See W. Prosser, HANDBOOK OF THE LAW OF TORTS 804-07 (4th ed. 1971). It differs from the other forms of that tort, liowever, in that it rests not on a concern for reputation or personal feelings but rather on the acknowledgement of a proprietary interest in the pecuniary value of a person's identity. Id. at 807; Comment, Transfer of the Right of Publicity: Dracula's Progeny and Privacy's Stepchild, 22 UCLA L. Rev. 1103, 1 103-04 (1975). See Zacchini v. Scripps-Howard Broadcasting Co., 433 U.S. 562,573 (1977).

32. 47 Ohio St. $2 d$ at $233-36,351$ N.E.2d at $460-62$. 
licity value of Zacchini's performance would place unconstitutional hinitations on the defendant's news coverage, the Supreme Court did not overlook the analogy to copyright primciples: "[T]he State's imterest [in recognizing a right of publicity] is closely analogous to the goals of patent and copyright law, focusing on the right of the individual to reap the reward of his endeavors . . . ."33 One factor the Court considered was the function of the right of publicity im protectimg an individual's interest in being coinpensated for past investments of time and effort and providing an incentive to produce future performances worthy of public attention. Simce the defendant's broadcast posed a threat to the economic value of Zacchini's performance, both of these interests were jeopardized. The Court also assessed the extent to which a limitation on the defendant's activities would conflict with first amendment values. It first noted that the real question in a right of publicity case is usually not whether publication of the information will be minimized or eliminated, but rather which party ought to do the publishing. The Court obviously believed that recognizing a property right in Zacchini's act would not seriously curtail public access to the performance. ${ }^{34}$ Second, the Court considered the internal limits of the right of publicity, notimg that the right would not prevent the defendant from reporting the facts surrounding plaintiff's act. The imtrusion on the free flow of information therefore was minimal. When the insubstantial effect on free speech was compared to the potential harm to the plaintiff's property interest, the Court found the balance to be in favor of the latter. "Wherever the line in particular situations is to be drawn between media reports that are protected and those that are not, we are quite sure that the First and Fourteenth Amendments do not immunize the media when they broadcast a performer's entire act without his consent." 35

The Court could have drawn the line elsewhere. Three Justices urged in dissent that plaintiff's proprietary right should give way whenever the defendant's use in part of a "routine portion of a regular news program" and there is no showing of "private or commercial exploitation."36 The point remains that private law doctrimes that create proprietary interests in forms of expression inust be analyzed carefully to insure that they do not infringe on the constitutional guarantees of free speech and free press. ${ }^{37}$ In some instances, the internal structure of the

33. 433 U.S. at 573.

34. Id. at 578.

35. Id. at 574-75.

36. $I d$. at 581 (dissenting opinion).

37. Paulsen v. Personality Posters, Inc., 59 Misc. 2d 444, 299 N.Y.S.2d 501 (Sup. Ct. 1968). See Factors Etc., Inc. v. Pro Arts, Inc., 579 F.2d 215, 222 (2d Cir. 1978), cert. denied, 99 S. Ct. 1215 (1979). 
private law doctrine may itself limit application to a constitutionally permissible sphere. In others, an external constitutional privilege must be imposed to prevent imterference with first amendment ideals.

The remamder of this Article will address the conflict between freedom of speech principles and property principles in copyright law, borrowing the approacli taken in cases weighing otlier private law doctrines against the first ainendment. First, the effects of the internal structure of copyright law will be examined. Then, where the internal accommodations in copyright law between property and first amendment interests are inadequate to protect constitutional rights fully, external constraints will be explored.

\section{II}

\section{THE INTERNAL ACCOMMODATION}

\section{A. Ideas and Expressions}

On the relationship of copyright to the first amendinent, as on so inany other aspects of the law of copyright, the work of Professor Melville Nimmer set the stage for nucli of the subsequent judicial and academic analysis. In 1970, he accurately forecast that the courts eventually would be required to "delineate the respective elaims of copyright and freedoin of speech." 38 In assessing the extent to which copyright might intrude upon the guarantees of free speecli and free press, Professor Nimmer stressed the fundamental principle that copyright protection does not extend to the ideas contained in the copyrighted work.

Long establislied by case law, ${ }^{39}$ the principle is now codified in the new Copyright Act. ${ }^{40}$ Copyright protection extends not to abstract ideas, but rather to the particular forn in which the ideas are expressed. ${ }^{41}$ For example, the author of two scholarly works that implicated Secretary of War Stanton in the assassmation of President Lincoln camiot object to the "borrowing" of the theory in a popular article. ${ }^{42}$ Similarly, the owner of the copyright in a graphic work sucl

38. Nimmer, Does Copyright Abridge the First Amendment Guarantees of Free Speech and Press?, 17 UCLA L. REV. 1180, 1185-86 (1970). For other early works that consider the problem, see Goldstein, Copyright and the First Amendment, 70 Colum. L. REv. 983 (1970); Sobel, Copyright and the First Amendment: A Gathering Storm?, 19 COPYRIGHT L. SYMP. 43 (1971).

39. See cases cited in 3 M. Nimmer, Nimmer on Copyright $\$ 13.03$ [A] n.10 (1978).

40. "In no case does copyright protection for an original work of authorship extend to any idea, procedure, process, system, method of operation, concept, principle, or discovery, regardless of the forn in which it is described, explained, illustrated, or enbodied in such work." 17 U.S.C. app. $\$ 102(\mathrm{~b})(1976)$.

41. See, e.g., Mazer v. Stein, 347 U.S. 201, 217 (1954).

42. Eisenschiml v. Fawcett Publications, Inc., 246 F.2d 598 (7th Cir.), cert. denied, 355 U.S. 907 (1957). 
as a photograph or painting receives no monopoly over the subject matter of the work. ${ }^{43}$ In these illustrations, the copyright owner generally is able to prohibit substantial copying of the language he chose to express his theory or the reproduction of his particular photograph or painting. Clearly the scope of protection cannot be limited to virtual duplication, or the protection in most instances would be illusory. In what is perhaps tlie most well-known decision on the scope of copyriglit protection, Judge Learned Hand stated:

It is of course essential to any protection of literary property, whether at common law or under the statute, that the right cannot be limited literally to the text, else a plagiarist would escape by immaterial variations. That has never been the law, but, as soon as literal appropriation ceases to be the test, the whole matter is necessarily at large . . . .44

Where then is the line separating the unprotected idea from the protected expression of the idea? Again, in the words of Judge Hand:

Upon any work, and especially upon a play, a great number of patterns of increasing generality will fit equally well, as more and more of the incident is left out. The last may perhaps be no more than the most general statement of what the play is about, and at times might consist only of its title; but there is a poimt in this series of abstractions where they are no longer protected, since otherwise the playright could prevent the use of his "ideas," to which, apart from their expression, his property is never extended. ${ }^{45}$

The Hand fornulation clearly does nothing to tarnisli copyright's reputation for evanescent distinctions. ${ }^{46}$ Nevertheless, it captures the essence of the idea-expression dichotoiny. At soine point, as the borrowing becoines more extensive, it seems fair to say that the second author is appropriating not only the ideas of the first but also the manner in whicli they are expressed. This solnetimes fragile distinction represents perliaps the most significant internal bulwark provided by copyright law against infringement of first amendment rights.

The Supreme Court has said that the values underlying the first amendment ${ }^{47}$ generally are well served by allowing an "uninhibited inarketpIace of ideas."48 If copyright law restricted the free flow of ideas, constitutional problems necessarily would arise. ${ }^{49}$ By limiting

43. See, e.g., Franklin Mint Corp. v. National Wildlife Art Exch., Inc., 575 F.2d 62 (3d Cir.), cert. denied, 99 S. Ct. 217 (1978).

44. Nichols v. Universal Pictures Corp., 45 F.2d 119, 121 (2d Cir. 1930), cert. denied, 282 U.S. 902 (1931).

45. Id.

46. See Folson v. Marsh, 9 F. Cas. 342, 344 (C.C.D. Mass. 1841) (No. 4,901).

47. See notes 17-23 and accompanying text supra.

48. Red Lion Broadcasting Co. v. FCC, 395 U.S. 367, 390 (1969).

49. Lee v. Runge, 404 U.S. 887, 892-93 (1971) (Douglas, J., dissenting from denial of certiorari). 
copyright protection to the particular forms of expression in which the ideas were originally contributed, however, copyright doctrime carefully preserves free access to ideas and avoids any such blatant confrontation with the first amendment. ${ }^{50}$

Many of the first amendinent challenges to copyright law that have been pressed on the federal courts can be analyzed in terms of the ideaexpression dichotomy. ${ }^{51}$ Although the Supreine Court has not yet dealt explicitly with these challenges, in the Zacchini case it noted with apparent approval that several federal courts had rejected such first amendment claims on the ground that copyriglit law does not restram the use of ideas. ${ }^{52}$ Indecd, in the Zacchini case itself the Court reached an analogous result with respect to the right of publicity. The Court was able to dismiss defendant's first amendment arguinent because the applicable state law did not operate to prevent the television station froin reporting the facts surrounding plaimtiff's performance. The defendant had gone further, however, and appropriated Zacchini's entire act-the "expression" in which his "idea" was conveyed. In effect, the Court held that free speech values could be adequately preserved without the use of plaintiff's expression. To the extent that the unrestrained use of ideas, as opposed to forms of expression, is sufficient to meet the goals of free speech, a separate first amendment privilege is unnecessary.

Several courts have applied this reasoning to first amendment challenges to copyright law. In Robert Stigwood Group Ltd. $v$. $O^{\prime} R e i l l y,{ }^{53}$ the plaintiff was the owner of the professional stage rights to the rock opera Jesus Christ Superstar. In a motion for a preliminary injunction against a touring company coinposed in part of Catholic priests, plaintiff alleged that the company had infringed the copyright to the opera by performing the work on more than fifty occasions. The court found that the company's net income from the perfornnances had been approximately $\$ 220,000$. The defendants argued that application of the copyright law would violate their rights to free speecli and the free exercise of their rights. The court rejected their constitutional defenses. The defendants were, of course, free to use the idea embodied in plaintiff's work and compose their own musical interpretation of the

50. Nimmer, supra note 38 , at 1191-92.

51. The distinction between idea and expression is one of degree, as is evident from the Hand formulation. In using the distinction as a safeguard against impermissible interference with freedoin of speech, it therefore is possible to fix the point at which hability arises in any particular instance by referring to the need to accommodate competing constitutional interests. See Goldstein, supra note 38 , at 1018 .

52. 433 U.S. at 577 n.13.

53. 346 F. Supp. 376 (D. Conn. 1972), rev'd on other grounds, 530 F.2d 1096 (2d Cir. 1976), cert. denied, 429 U.S. 848 (1977). 
final days of Christ. The first amendment did not require, however, that they be able "to avoid the expenditure of time and skill necessary to evolve their own expressions." 54

More recently, the United States Court of Appeals for the Ninth Circuit used a similar rationale to reject a first amendment argument in Sid \& Marty Krofft Television Productions, Inc. v. McDonald's Corp. ${ }^{55}$ The defendant had engaged im an advertising cainpaign featuring the inhabitants of "McDonaldland," a pleasant neighborhood under the leadership of Mayor McCheese. The court found that the McDonaldland campaign had been copied from plaintiffs' "H.R. Pufnstuf" television series, a weekly children's prograin. Since defendant used substantially the same form of expression as plamtiffs, the court upheld the trial judge's finding of infringeinent. In rcsponse to McDonald's first amendment claim, the court stated:

the impact, if any, of the first amendment on copyright has not been discussed by the [Supreme] Court. We believe this silence stems not from neglect but from the fact that the idea-expression dichotomy already serves to accommodate the competing interests of copyright and the first amendinent. The "inarketplace of ideas" is not limited by copyright because copyright is limited to protection of expression. ${ }^{56}$

Cases such as Robert Stigwood and McDonald's are untroublesoine. The defendants are free to communicate any inessage or idea they choose, including those contamed in the appropriated works. Since they can inake no showing that the particular form of expression adopted by the copyright owner is somehow necessary to the exercise of their right of free speech, their first ainendinent challenges are easily rejected. The idea-expression dichotomy provides a de facto accommodation between copyright and free speech by assuring an unrestrained flow of ideas.

A potential inadequacy in this accommodation arises when an idea can only be expressed in a maumer substantially similar to the copyrighted form of expressions. Yet even in such situations copyright doctrime seems to avoid possible interference with constitutional rights. In Herbert Rosenthal Jewelry Corp. v. Kalpakian, ${ }^{57}$ for exainple, the plaintiff had copyrighted a jeweled pim in the shape of a bee. The copyright, of course, did not grant plaintiff a monopoly over the idea of making a pin im the shape of a bee. Any given expression of the idea, however, will be substantially similar to that used by the copyright

54. Id. at 384 (quoting Nimmer, supra note 38 , at 1203).

55. 562 F.2d 1157 (9th Cir. 1977).

56. Id. at 1170 (footnote omitted). For a decision using the idea-expression dichotomy to reject a first amendment defense to copyright infringement in a crimmal context, see United States v. Bodin, 375 F. Supp. 1265 (W.D. Okla. 1974).

57. 446 F.2d 738 (9th Cir. 1971). 
holder-if you've seen one jewel-encrusted bee, you've seen them all. The Nimth Circuit concluded that the idea and its expression essentially were inseparable; copymg the expression therefore was permissible since the alternative was a monopoly over the idea. The First Circuit reached an analogous result in Morrissey v. Procter \& Gamble Co. ${ }^{58}$ denying copyright protection to a set of instructions for a sales promotional sweepstakes on the ground that the plaintiff should not be permitted to appropriate an idea by copyrighting its various expressions. ${ }^{59}$ Thus when idea and expression inerge so that the free use of the former requires the free use of the latter, copyright doctrime responds by denying protection even to expression.

\section{B. Fair Use as Free Speech}

The idea-expression dichotolny is the basic internal inechanism to accommodate copyright doctrine and the first amendment. It functions effectively in any situation in which the purposes of free speech are adequately served by preserving the free access to ideas, without the need for similar access to a particular form of expression. In some instances, however, the values inherent in the rights of free speech and free press demand inore than access to abstract ideas-they require the use of the particular form of expression contained in a copyrighted work. This category of situations extends far beyond the narrow class of cases previously considered in which idea and expression merge. It covers a variety of instances in which idea and expression are distinguishable, but true freedom of speech demands unrestricted access to both. In these situations the idea-expression dichotony offers no assistance.

When only a minimal appropriation of expression is needed to satisfy constitutional requirements in a particular instance, the "substantially similar" test for copyright infringement ensures the necessary latitude. Under this test, an appropriation of copyrighted expression is actionable only if it results in substantial similarity between the copy and the original. ${ }^{60}$

A more broadly applicable restraint agamst the intrusion of copyright law into constitutional preserves is the doctrine of fair use. The nost frequently quoted definition of fair use describes it as a "privilege in others than the owner of a copyright to use the copyrighted material in a reasonable manner without his consent, notwithstanding the mo-

58. 379 F.2d 675 (1st Cir. 1967).

59. See also Baker v. Selden, 101 U.S. 99 (1880); Continental Cas. Co. v. Beardsley, 253 F.2d 702 (2d Cir.), cert. denied, 358 U.S. 816 (1958).

60. 3 M. NimmeR, supra note $39, \S 13.03$. 
nopoly granted to the owner by the copyright." ${ }^{\text {. }}$ Although the term "fair use" has sometimes been employed simply to designate the absence of a "substantial" taking, ${ }^{62}$ it allows much more extensive borrowing of copyrighted material than does the substantial similarity requirement. It can operate as a defense even when there has been a substantial appropriation of expression. ${ }^{63}$

Iromically, although perhaps not surprisingly, it was a case that may have been wrongly decided that first focused attention on the role of fair use doctrine in reconciling the property interests of copyright with the first amendment guarantees of free speech and free press. The plaintiff in Rosemont Enterprises, Inc. v. Random House, Inc. ${ }^{64}$ had requested a preliminary injunction barring the publication and distribution of a biography of Howard Hughes, alleging that the book infringed the copyrights on three articles about Hughes published twelve years earlier in Look Magazine. Rosemont had purchased the copyrights to these articles shortly before commencing the litigation. The articles contained some 13,500 words, the biography approximately 116,000 . In granting the injunction, the district court had found that the biography quoted about 256 words from the articles. Defendant conceded that another eighty words were paraphrased, and the district court found at least twelve additional instances of apparent paraphrasing. ${ }^{65}$ The Second Circuit vacated the preliminary injunction on the basis of fair use. It rejected the district court's conclusion that commercial unotives on the part of the defendant prevented application of the fair use doctrine. After discussing the social value of the biographer's act, the court revealed the basis of its decision:

By this preliminary injunction, the public is being deprived of an opportunity to beconie acquainted witl the life of a person endowed with extraordinary talents who, by exercising these talents, inade substantial

61. H. Ball, The Law of Copyright and Literary Property 260 (1944). The Register of Copyright provides the following definition: "That term [fair use] eludes precise definition; broadly speaking, it means that a reasonable portion of a copyrighted work may be reproduced without permission when necessary for a legitimate purpose which is not competitive with the copyright owner's market for his work." HOUSE COMM. ON THE JUDIClaRY, 87TH CONG., 1sT Sess., Copyright LaW ReVision, Report of the Register of Copyrights on the General Revision of THE U.S. Copyright LAW 24 (Comm. Print 1961) [hereinafter cited as REgISTER of COPYRIGHTS REPORT].

62. Nichols v. Universal Pictures Corp., 45 F.2d 119, 121 (2d Cir. 1930) (Hand, J.), cert. denied, 282 U.S. 902 (1931); 3 M. NIMMER, supra note 39, $\S 13.05$ n.9. The term has also been used to indicate the appropriation of unprotected ideas. Id. n.11.

63. See, e.g., Williams \& Wilkins Co. v. United States, 487 F.2d 1345 (Ct. Cl. 1973), affd by an equally divided court, 420 U.S. 376 (1975).

64. 366 F.2d 303 (2d Cir. 1966), cert. denied, 385 U.S. 1009 (1967).

65. 256 F. Supp. 55, $61-62$ (S.D.N.Y.), vacated, 366 F.2d 303 (2d Cir. 1966), cert. denied, 385 U.S. 1009 (1967). The thoughts of a young associate or law clerk who, after 19 or 20 years of formal education, is relegated to counting the words in old magazine articles, are best left unrecorded. 
contributions in the fields to which he chose to devote his unique abilities ... Thus, in balancing the equities at this time in our opinion the public interest should prevail over the possible dannage to the copyright owner. ${ }^{66}$

The Rosemont result itself may be questionable. Defendant made no showing of any need for the rather extensive paraphrasing of the Look articles. The court could well have held that there was no need to permit any appropriation of expression at all, or at least that the defendant exceedcd the use required to accomplish his purpose. ${ }^{67} \mathrm{Nev}$ ertheless, the decision clearly indicatcs the pivotal role that free speech interests can play in fair use decisions. ${ }^{68}$

The fair use doctrine has been codified in section 107 of the new Act. The statute lists four considerations for determining whether a particular usage is a fair use: (1) the purpose and character of the use, mcluding whether the use is of a commercial nature or is for nonprofit educational purposes; (2) the nature of the copyrighted work; (3) the amount and substantiality of the portion used in relation to the copyrighted work as a whole; and (4) the effect of the use on the potential market for or value of the copyrighted work. ${ }^{69}$

The recent case of New York Times Co. v. Roxbury Data Interface, Inc. ${ }^{70}$ presents a inodern apphication of the doctrine, with emphasis on the four factors noted in section 107. The New York Times Company publishes an annual index that lists under various headings references to pages and columns of New York Times newspapers in which information concerning that topic or person appears. The defendant was in

66. 366 F.2d at 309.

67. See Nimmer, supra note 38, at 1201-03. It should be noted, however, that the decision was made in the context of reviewing a preliminary injunction. The court was sensitive to the problems associated with restraining publication of a book. 366 F.2d at 311. The result may therefore be justified on the grounds that the plaintiff simply failed to establish the legal and factual foundation necessary to justify preliminary rehief.

68. For a recent decision that vividly demonstrates the utility of the fair use doctrine in protecting first amendment interests in the classic context of a pohitical campaign, see Keep Thomson Governor Comm. v. Citizens for Gallen Comm., 457 F. Supp. 957 (D.N.H. 1978).

69. 17 U.S.C. app. $\S 107$ (1976). The full text reads:

Notwithstanding the provisions of section 106, the fair use of a copyrighted work, including such use by reproduction in copies or phonorecords or by any other means specified by that section, for purposes such as criticism, comment, news reporting, tcaching (includimg multiple copies for classroom use), scholarship, or research, is not an infrimgement of copyright. In determining whether the use made of a work in any particular case is a fair use the factors to be considered shall include-

(1) the purpose and cliaracter of the use, including whether such use is of a coinmercial nature or is for nonprofit educational purposes;

(2) the nature of the copyrighted work;

(3) the amount and substantiality of the portion used in relation to the copyrighted work as a whole; and

(4) the effect of the use upon the potential market for or value of the copyrighted work.

70. 434 F. Supp. 217 (D.N.J. 1977). 
the process of publishing a twenty-two volume Personal Name Index to the New York Times Index, covering the years 1851 to 1974. The defendant's index consisted of personal names extracted from the annual mdices witl citations to the pages of the New York Times Index on which references to the names appear. Thus, a researcher imterested in locating New York Times articles concerning Williain O. Douglas could first find the appropriate entry in defendant's Personal Name Index. This entry would then refer her to the volumes and pages of plaintiff's annual indices $\mathrm{m}$ which entries relating to Douglas appear. Thicse entries would in turn refer to specific articles in the New York Times. Without defendant's index, the researcher would be forced to search through eacli annual volume of the Times Index for relevant articles. The New York Times Company moved for a preliminary injunction, arguing that the copying of the names from its annual index constituted copyright infringernent.

Although the new Copyright Act was not yet in effect, ${ }^{71}$ the court applied the section 107 criteria in deciding whether to allow the defense of fair use. The court first considered the purpose and character of the use, finding that it served two purposes. First, from the defendant's perspective it was an attempt to turn a profit. The court held that a commercial inotive, although relevant to its determination, did not preclude a finding of fair use. ${ }^{72}$ Second, the court found that the use "will serve the public interest in the dissemmation of information." 73 The recognition of this "public interest" as a relevant factor in assessing the purpose and character of a use permits the fair use doctrine to assist in accommodating copyright and freedom of speech.

The second factor in section 107 is the nature of the copyrighted work. The court stated that since the New York Times Index is more a product of diligence than creativity, the fair use doctrine slould permit greater license than it might for the use of inore original works. ${ }^{74}$

The court made several important observations in regard to the third factor in section 107, the annount and substantiality of the use. It noted that a purely quantitative test was inadequate because it fails to take into account the importance of the appropriated material and the necessity of using portions of the copyrighted work in order to prepare defendant's product. "For all practical purposes, defendants could not publish their personal name mdex witlout copying the names from the Times Index."75 This necessity criterion represents another mechanism

71. Id. at 221.

72. Id.

73. Id.

74. Id.

75. Id. at 223. 
within fair use doctrine for incorporating first ainendment concerns. If prohibiting the challenged use is tantamount to prohibiting the production of a work that would further the public interest in the dissemination of inforination, the fair use balance tends toward permitting the appropriation.

Finally, the court considered the fourtli and last factor in section 107, "the effect of the use upon the potential market for or value of the copyrighted work." The court found that defendant's index did not compete with the Times Index. Since the Personal Name Index contained only citations to the Times Index, it did not serve as a substitute for the plaintiff's work, and in fact could only be used in conjunction with it. ${ }^{76}$

After balancing the foregoing factors, the court concluded that the defendant's appropriation of materials might well be justified by the fair use doctrine. The New York Times Coinpany had failed to establish a likelihood of success sufficient to warrant preliminary relief. ${ }^{77}$

Roxbury Data illustrates the capacity of modern fair use doctrine to ease inuch of the inherent tension between copyright law and the first amendment. In focusing attention on the public interest in the flow of information, it seeks to further many of tlie same interests as the right of free speech. Yet at the same time, im assessing the necessity for a particular type or degree of use, it seeks to insure that copyriglt interests are not sacrificed needlessly where alternative means of producing the desired result are available. ${ }^{78}$

76. The court ruled, perhaps erroneously, that the plaintiffs would suffer no economic injury as a result of the defendant's use. Plaintiff argued that the value of a work can be diminished other than through direct competition. The publication of defendant's Personal Name Index undoubtedly will have an adverse effect on plaintiff's ability to exploit its copyright by producing a personal name compilation of its own. In weighing the potentially adverse economic impact of the use, the court may well have been influenced by the fact that the plaintiff had twice rejected proposals to create its own personal naine imdex, and the official who reached these decisions stated that "he had no information which would cause hin to change his prior estimates." Id. at 225. The court further argued that defendants had not copied the substance of plaintiff's copyright. The defendant's compilation contained nothing more than citations to the Times Index citations; it did not appropriate the actual references to plaintiff's newspaper. Id. at 224-25. This is really an argument that there is no substantial similarity between the works and therefore no mfrimgement. The availability of such an argument should preclude the need even to consider the fair use defense.

77. Id. at 226-27. The fair use analysis was made in the context of a motion for a preliminary imjunction. No doubt this context made the decision less difficult.

78. Compare Marvin Worth Prods. v. Superior Films Corp., 319 F. Supp. 1269 (S.D.N.Y. 1970) (preliminary injunction granted prohibiting the use in defendant's movie of material froin two copyrighted books about comedian Leuny Bruce simce the defendant could (and did) portray Bruce's style and manner without the use of the copyrighted material) with Rohauer v. Killiain Shows, Inc., 379 F. Supp. 723 (S.D.N.Y. 1974), rev'd on other grounds, 551 F.2d 484 (2d Cir.), cert. denied, 431 U.S. 949 (1977) (defense of fair use rejected for the unauthorized showing of the movie The Sons of the Shiek, on the ground that there was no discermible public interest involved) and Willians \& Wilkins Co. v. United States, 487 F.2d 1345 (Ct. Cl. 1973), aff'd by an equally 
The legislative history accompanying the new Copyright Act lists a variety of appropriate situations for invoking the fair use doctrine. ${ }^{79}$ One area in which tle doctrine is particularly successful in integrating copyriglt and free speech principles is in cases involving the use of copyright material in parodies. ${ }^{80}$

Berlin v. E.C. Publications, Inc. ${ }^{81}$ is illustrative. The defendant, publisher of Mad Magazine, produced parodies of the lyrics of several popular songs. ${ }^{82}$ Since the defendant copied neither the words nor the inusic of the copyrighted songs (the imstructions simply indicated "Sung to the tune of"), the court held that the works were not substantially similar. It nevertheless proceeded to discuss the general question of parody and copyright:

[A]s a general proposition, we believe that parody and satire are deserving of substantial freedom-both as entertainment and as a form of social and literary criticism. . . . At the very least, where, as here, it is clear that the parody has neither the intent nor the effect of fulfilling the demand for the original, and where the parodist does not appropriate a greater amount of the original work than is necessary to "recall or conjure up" the object of his satire, a finding of infringeinent would be improper. ${ }^{83}$

This "conjure up" test permits the parodist, under the doctrine of fair use, to appropriate froin the copyrighted work the minimum amount of expression needed to remind the audience of the basic style and character of the parodied work. It thus insures that copyright will not operate to curtail this forn of speech, while simultaneously protecting the copyriglit owner's property riglit in expression to the maximum extent com-

divided court, 420 U.S. 376 (1975) (photocopying of inedical journals is justified by the public interest).

79. Both the House and Senate Reports contain the following list taken from the Register of Copyrights Report, supra note 65, at 24. ment. Quotation of excerpts in a review or criticism for purposes of illustration or coin-

Quotation of short passages in a scholarly or technical work, for illustration or clarification of the author's observations.

Use in a parody of some of the content of the work parodied.

Summary of an address or article, with brief quotations, in a news rcport.

Reproduction by a library of a portion of a work to replace part of a damagcd copy. Reproduction by a teacher or student of a sinall part of a work to illustrate a lesson. Reproduction of a work in legislative or judicial proceedings or reports.

Incidental and fortuitous reproduction, in a newsreel or broadcast, of a work located at the scene of an event being reported.

H.R. REP. No. 94-1476, supra note 4, at 65; S. REP. No. 94-473, supra note 4, at 61-62.

80. See Comment, Parody, Copyrights and the First Amendment, 10 U.S.F. L. Rev. 564 (1976).

81. 329 F.2d 541 (2d Cir.), cert. denied, 379 U.S. 822 (1964).

82. "A Pretty Girl Is Like a Melody" was transformed into "Louella Scliwartz Describes Her Malady," and "The Last Time I Saw Paris" becaine "The First Time 1 Saw Maris." Id. at 543. 83. Id. at 545 . 
patible with the free speech interests. ${ }^{84}$

The ability of fair use doctrine to reconcile copyright law with free speech has led some to conclude that the doctrine is in essence a constitutional one, with its contours determined by the first amendment. ${ }^{85}$ This conclusion is unnecessary and perhaps unwise. The fair use doctrine simply immunizes from hability certain invasions of statutorily created property rights. That it may operate in some instances to avoid potential conflicts between those property rights and the interests protected by the first amendment need not elevate the doctrine to constitutional status. ${ }^{86}$ Indeed, the purposes of both copyright and constitutional law are better served if fair use is seen as merely a substantive rule of copyright law that can on occasion reduce the inherent tension between free speech and property rights in expression.

\section{III}

\section{The External Constraint}

\section{A. Residual Tensions}

The preceding survey of the internal structure of modern copyright doctrine illustrates the reinarkable degree to which copyright law effectuates the constitutional policy of encouraging creative activity while simultaneously avoiding interference witls principles of free speech and free press. Yet the accommodation is incomplete. Tlere remain situations in which coinpelling free speech interests are inadequately protected by the idea-expression dichotomy and traditional fair use

84. See, e.g., Walt Disney Prods. v. Mature Pictures Corp., 389 F. Supp. 1397 (S.D.N.Y. 1975). The first ainendment issue was directly raised in a recent parody case before the Ninth Circuit. Walt Disney Prods. v. Air Pirates, 581 F.2d 751 (9th Cir. 1978), cert. denied, 99 S. Ct. 1054 (1979). The defendants had published underground comics in which several familiar Disney clraracters were cast in various escapades which "could not fairly be called innocent." 345 F. Supp. 108, 110 (N.D. Cal. 1972). The court concluded that the fair use defense was not apphicable since the defendants had taken inore than permitted under the Berlin rationale. The court used the idea-expression distinction to dismiss defendants' separate first ainendinent arguinent. "Because the defendants here could have expressed their theine without copying Disney's protected expression, Sid \& Marty Krofft requires that their First Amendinent challenge be dismissed." 581 F.2d at 759. See notes 55-56 and accompanying text supra. The idea-expression diclotoiny does not adequately protect the free speech interests in such a case, lowever, since soine appropriation of expression is basic to the very concept of parody. It is instead the fair use doctrime that inaintains the internal flexibility needed to avoid a direct confrontation with first amendinent interests.

85. See, e.g., Rosenfield, The Constitutional Dimensions of "Fair Use" in Copyright Law, 50 Notre DAME LAw. 790 (1975) (concluding that the fair use doctrine has constitutional status under both the flrst and ninth amendinents).

86. See, e.g., Italian Book Corp. v. American Broadcasting Cos., Inc., 458 F. Supp. 65 (S.D.N.Y. 1978). In that case defendant broadcast in its television news coverage of a parade a band's performance of a work in which the plaimtiff claimed copyright. Since the defendant's use was privileged under the fair use doctrine, it was unnecessary to consider the constitutional issues raised by defendant's first amendment claim. Id. at 67 . 
doctrine. These situations require recognition of a separate first aniendment privilege.

The case of Time, Inc. v. Bernard Geis Associates ${ }^{87}$ provides an example. On November 22, 1963, Abrahanı Zapruder, a Dallas dressmaker, made his way to the top of a concrete pedestal in order to obtain an unobstructed view of the Presidential motorcade that was about to proceed down Elm Street. He had brought his home movie camera, equipped with a telephoto lens. The film he took was to become perhaps the most significant evidence in the investigation of the assassination of President John F. Kennedy. Three days after the assassmation, Life Magazine purchased the Zapruder film for $\$ 150,000$. Life published thirty frames from the fihn in its next edition. A week later it published nine frames as part of a special memorial edition. The film was brought to Washington and displayed to the FBI, the Secret Service, and the Warren Commission appoimted by President Johnson to investigate the assassmation. The Commission rehed heavily on the film in making its report. It included six frames in the mam body of the report and 160 in a volume of exhibits. A copy of the film was placed in the National Archives and made available for viewing, though not for reproduction.

The Warren Commission Report generated considerable criticism. Life itself published some of the Zapruder frames in another article discussing the controversy surrounding the Warren Commission Report and concluding that the case should be reopened. Defendant Thompson, an assistant professor of philosophy at Haverford College, was convinced that the Report was in error. Thompson became a consultant to Life and, remaining at their offices one evening, photographed the Zapruder frames. He later wrote a book on the assassmation entitled Six Seconds in Dallas. The book included copies of twenty-two of the copyrighted movie frames.

Life brought an action for copyright infringement and moved for suininary judgnient on the issue of hability. It alleged that it currently was planning a inotion picture project involving the film and that frames also would be used in future issues of inagazines and books.

It is hard to nnagime a more compelling case for requiring free access to a copyrighted work. A President had been inurdered. The official report on his death was meetimg with a rising tide of skepticism and suspicion. To have a meaningful public debate, it seemed crucial to test and illustrate opposing theories agamst the actual visual record of the events. Access to the bare ideas and facts contained in the copyrighted movie frames would be insufficient-a verbal description could

87. 293 F. Supp. 130 (S.D.N.Y. 1968). 
not substitute for use of the photographs themselves. The idea-expression dichotoiny therefore was inadequate to insure that copyright protection of the movie frames would not inhibit public dialogue. Access to the film may have been justified under the first ainendinent. Instead, the court chose the fair use doctrine as the means of providing the necessary access to expression.

After quoting the fair use provision from the copyright revision bill pending in Congress, the court stated: "In determining the issue of fair use, the balance seems to be in favor of defendants. There is a public interest in having the fullest inforination available on the inurder of President Kennedy. Thoinpson did serious work on the subject and has a theory entitled to public considcration." 88 In analyzing the fair use issue the court considered potential economic harm to the copyright owner. It found that since the dcfendant did not publish inagazines, and the plaintiff did not offer the Zapruder pictures for sale as such, there was no direct competition and hence no immediate injury. The court found the financial effect on future uses of the frames by the plaintiff in novies or books to be speculative. It went on to conclude that the defendant's book actually might enhance the value of the Life copyrights.

The question of economic detriment to the copyright owner lies at the core of the fair use defense. ${ }^{89}$ Fair use doctrine operates not only to remove unnecessary obstacles to the use of copyrighted works, but also to further the constitutional policy of encouragimg science and the useful arts through the granting of copyrights. ${ }^{90}$ If a work that appropriates copyrighted expression functions in part as a substitute for the original, the economic incentive offered by the copyright systen is diluted.

The fair use privilege generally has permitted only those appropriations that do not seriously undermine the basic policy of economic incentive. $^{91}$ For examplc, the fair use privilege to quote portions of copyrighted works for purposes of criticism or review ${ }^{92}$ is compatible with the protection of economic incentives, since the resulting work

88. Id. at 146.

89. "The fourth factor listed in Section 107 is the effect of the use upon the potential market for or value of the copyrighted work.' If one looks to the fair use cases, if not always to their stated rationale, this emerges as the most important, and indeed, central fair use factor." $3 \mathrm{M}$. NIMMER, supra note 39, § 13.05[A] (footnotes omitted). The Report on the General Revision of the United States Copyright Law similarly limits application of the fair use doctrine to situations in which the use "is not competitive with the copyright owner's market for his work." Register of Copyrights Report, supra note 61, at 24.

90. Rosemont Enterprises, Inc. v. Random House, Inc., 366 F.2d 303, 307 (2d Cir. 1966), cert. denied, 385 U.S. 1009 (1967).

91. See generally 3 M. NIMMER, supra note $39, \S 13.05$.

92. 17 U.S.C. app. $\S 107$ (1976). 
performs a different function than the original and is not a market substitute. Similarly, the "conjure up" test of fair use in parody cases" ensures that the inaterial borrowed for the purposes of parody is not so extensive that the parody becoines simply a competitive variation of the original.

Many traditional fair use factors can be seen as tests for economic competition. Thus, in calling upon courts to examine the extent of appropriation, fair use doctrine focuses attention on the degree to which the defendant's work may function as a substitute for that of the plamtiff. An examination of the purpose of the defendant's use may reveal an intention to benefit from the market demand for the appropriated expression. Similarly, consideration of the nature of the copyrighted work can fix the scope of plaintiff's econormic interests by indicating the inarkets that the work inay be expected to serve.

Appropriations of expression that result in more than minimal economic harm to the copyright owner are inconsistent with the very purpose of copyright. In its effort to establish the necessary foundation for its decision, the court in Bernard Geis was compelled to minimize its estimate of the potential economic impact of the defendant's use of the Zapruder frames. Yet the plaintiff's copyright, if fully enforced, would give it complete control over what may be the inost important documentary film in existence. Indeed, the defendant was so anxious to use the frames that he offered to pay a royalty equal to the total profits froin his book in return for a license. ${ }^{94}$ The defendant's use of the film frames would not prevent Life from pursuing its plans to use the pictures in books, magazines and film formats. It could serve, however, as a substitute for many of those interested im seeing the key Zapruder frames. It is difficult to accept the court's conclusion that the value of the copyright was not impaired. The appropriateness of invoking the fair use doctrine in this case therefore inust be questioned. ${ }^{95}$

Assuming that the defendant ought to have access to the Zapruder frames, why slould it inatter that the fair use doctrine is employed to reach the desired result rather than the first anendment? The reason is that the fair use doctrine, like a sweater borrowed by an older brother or sister, will never quite fit once it is returned to its rightful place. In order to allow the fair use defense in Bernard Geis, the court essentially was obliged to loold that the potential impact of defendant's use on the

93. See text accompanying notes 81-84 supra.

94. 293 F. Supp. at 138.

95. Nimmer, supra note 38, at 1201. A similar argument might be made with respect to the application of the fair use doctrine in New York Times Co. v. Roxbury Data Interface, Inc., 434 F. Supp. 217 (D.N.J. 1977), although the potential economic injury appears to be less certain in that case than in Bernard Geis. See note 76 supra. 
future exploitation of the film by the plaintiff was merely speculative. If this holding indicates that a plaintiff must prove actual damage in order to rebut a fair use defense, it severely undermines the economic mcentive rationale of copyright law. Such a test confuses questions of liability with questions of damages. ${ }^{96}$ It inay be all but impossible for a plaintiff to prove actual damage with respect to future attempts to exploit the copyright. That section 504 of the Copyright Act ${ }^{97}$ specifically permits a plaintiff to elect statutory rather than actual damages indicates that proof of actual damage is not required to establish liability. ${ }^{98}$ If the evidence establishes that defendant's use will tend to prejudice the market value of the plaintiff's work, the fair use defense generally should not be available..$^{99}$

The fair use defense is a substantive rule of copyright law designed to further the constitutional policy embodied in the copyright clause. It promotes the progress of science and of the arts by removing those barriers to use that are not needed to preserve the economic incentive to produce. The first amendment, however, demands inuch more. It incorporates no such goal of economic encouragement. When the objectives of free speech require access to the expression of another, the property interest created by copyright law must yield, regardless of the economic impact. Abridgements of the right of free speech do not become tolerable because they spring from the exercise of the copyright power rather than soine other source of federal authority. Yet recognizing the defense of fair use in cases involving significant economic larn to the copyright owner invites distortion of that doctrine. In all probability, such distortion cannot be confined to the ill-defined interface between copyright and free speech, but will almost inevitably influence the contours of the entire doctrine. The result could jeopardize the contmued viability of copyright law by threatening the system of economic incentives upon which it is founded. ${ }^{100}$

The first amendment on occasion inay dernand access to copyrighted expression, but it does not demand that the fair use doctrine be the inechanisin for achieving that result. This of course does not mean that fair use can have no role in accommodating copyright and free speech interests. To the contrary, fair use doctrine often does act to

96. 3 M. NIMMER, supra note $39, \S 1305[\mathrm{E}]$.

97. 17 U.S.C. app. $\$ 504$ (1976).

98. "[T] he plaimtiff in an infringement suit is not obliged to submit proof of damages and profits and may choose to rely on the provision for minimum statutory damages." H.R. REP. No. 94-1476, supra, note 4, at 161.

99. See Fried, Fair Use and the New Act, 22 N.Y.L. ScH. L. Rev. 497, $499-509$ (1977).

100. The converse problem also may arise if fair use is seen as the sole means of accommodating first amendment concerns-there may be a tendency to give inadequate weight to the free speech interests in an effort to preserve the traditional limits of the fair use privilege. 
permit the access to expression that may be required by the first amendment. To avoid undermining the utility of the doctrine, however, it should do so only where the defendant's use causes no significant economic injury to the copyright owner. If further accommodation is needed, it should be found elsewhere.

\section{B. The First Amendment Privilege}

If the fair use doctrine is not transforned into the ultimate guardian of first amendment interests, the conflict between copyright and free speech remains partially unresolved. The tension persists im situations in which a defendant establishes a first amendment mterest in inaking substantial use of the copyrighted expression of another in a inanner that threatens to cause significant econoinic harm to the copyright owner. In this narrow though significant area, substantive copyright doctrine does infringe on constitutionally protected rights. It is necessary therefore to recognize an independent first amendment privilege that would operate as an external limitation on the scope of the proprietary interest established by copyright. Such a privilege would ensure a right of access to copyrighted inaterials commensurate with the requirements of the first amendment.

In most cases in which the issue has been argued, the courts have rejected such a first amendment defense. ${ }^{101}$ But this apparent judicial reluctance to recognize a first amendment privilege may be due to the inappropriateness of the defense in the situations in which it has been raised. Indeed, in two decisions rejecting first amendinent arguments on the facts, the courts have noted that the constitution might require recognition of an independent privilege in soine limited instances. ${ }^{102}$

101. See Sid \& Marty Krofft Television Prods., Inc. v. McDonald's Corp., 562 F.2d 1157, 1170 (9th Cir. 1977) (first amendment defense rejected since defendant could not establish any coinpelling need to appropriate the expression einbodied in plaintiffs characters). Other cases that reject a first amendment defense also involve situations in which there is no free speech interest requiring the appropriation of expression. See, e.g., Dealer Advertising Dev., Inc. v. Barbara Allan Financial Advertising, Inc., 197 U.S.P.Q. 611 (W.D. Mich. 1977); United States v. Bodin, 375 F. Supp. 1265 (W.D. Okla. 1974); McGraw-Hill, Inc. v. Worth Publications, Inc., 335 F. Supp. 415 (S.D.N.Y. 1971). Other courts simply have treated first anendinent interests as coextensive with the fair use defense. Keep Thompson Governor Comm. v. Citizens for Gallen Comm., 457 F. Supp. 957, 960 (D.N.H. 1978); H.C. Wainwright \& Co. v. Wall St. Transcript Corp., 418 F. Supp. 620, 624 (S.D.N.Y. 1976), affd sub nom. Waimwright Sec. Inc. v. Wall St. Transcript Corp., 558 F.2d 91 (2d Cir. 1977), cert. denied, 434 U.S. 1014 (1978).

102. "Some day, legitimate in-depth news coverage of copyrighted, small-circulation articles dealing with areas of general concern may require courts to distinguish between the doctrine of fair use and 'an emerging constitutional limitation on copyright contamed in the first amendinent." W Wamwright Sec. Inc. v. Wall St. Transcript Corp., 558 F.2d 91, 95 (2d Cir. 1977), cert. denied, 434 U.S. 1014 (1978) (quoting Nimmer, supra note 38, at 1200); "There may be certain rare instances when first amendment considerations will operate to limit copyright protection for graphic expressions of newsworthy events.” Sid \& Marty Krofft Television Prods., Inc. v. McDon- 
A federal district court in Florida apparently has become the first to decide a copyright infringement suit expressly on first amendment grounds in the recent case of Triangle Publications v. Knight-Ridder Newspapers, Inc. ${ }^{103}$ Iromically, the free speech interests at stake in Triangle Publications probably could have been protected adequately by a proper invocation of the fair use doctrine.

The defendant, publisher of the Miami Herald, began an advertising campaign in the fall of 1977 to promote a new television supplement to its Sunday edition. The campaign took the form of newspaper and television inessages that compared the new supplement with plaintiff's publication, TV Guide. The advertisennents displayed the cover of an issue of TV Guide to facilitate comparison. ${ }^{104}$ The plaintiff requested both preliminary and permanent injunctions against the use of its magazine, arguing that the advertisements infringed its exclusive right to display the copyrighted work pursuant to section 106(5) of the new Copyright Act. ${ }^{105}$

The court had little diffieulty concluding that the TV Guide copyright extended to the cover as well as the contents of the magazine and that the defendant's use constituted a display of the work for purposes of the Copyriglit Act. ${ }^{106}$ Its treatment of the fair use defense is inore troublesome. In loolding that the defendant's "commercial criticism" did not fall within the fair use doctrine, the court approaclied the issue from an extraordimarily narrow perspective. While a commercial motive is relevant to a determination of fair use under section 107, the legislative history clearly indicates that it was not intended to be determinative. ${ }^{107}$ The court nonetheless was unable to find in the statute tlee inherent flexibility that historically lias characterized the defense. ${ }^{108}$ In concluding that the display of the TV Guide cover as part of the coinparative advertising campaign did not fall within the aunbit of fair use, the court failed to analyze correctly the critical issue of economic harnn. The plaintiff suffered absolutely no economic injury whatever from the

ald's Corp., 562 F.2d 1157, 1171 (9th Cir. 1977) (citing Time, Inc. v. Bernard Geis Assocs., 293 F. Supp. 130 (S.D.N.Y. 1968)).

103. 445 F. Supp. 875 (S.D. Fla. 1978).

104. Two television commercials that formed part of the campaign illustrate its basic tenor. In one, Goldilocks compares the relative sizes of $T V$ Guide, the Herald supplement and a larger magazine, concluding that the Herald supplement is the perfect size. In another, the basic theme is that a purchaser of $T V$ Guide receives only that, whereas a purchaser of the Herald supplement receives an extra-the remaimder of the Sunday Miami Herald newspaper. Id. at 876-77.

105. 17 U.S.C. app. \& 106(5) (1976).

106. 17 U.S.C. app. $\S \S 101,106(5)$ (1976).

107. H.R. REP. No. 94-1476, supra note 4, at 66; S. REP. No. 94-473, supra note 4, at 62.

108. $445 \mathrm{~F}$. Supp. at 880 . The court also attempted to equate fair use with uses intended or coutemplated by the copyright owner. Id. at $880-81$. This is in essence a theory of fair use based on imphied consent, and simply is not in keeping with either the historical development or present scope of the doctrime. See 3 M. NIMMER, supra note 39, § 13.05 . 
alleged infringement of its copyright. If the plaintiff loses a significant share of its present market, that would result not from the display of plaintiff's cover in defendant's advertising but frow commercial competition with a work that does not in any way make use of plaintiffs copyrighted inaterial. The alleged infringement itself causes no injury to the plaintiff because it does not in any inanner substitute for the plaintiff's product. It is difficult to believe that anyone purchases the inagazine simply to ponder the cover-the only part reproduced by the defendant. Any harm suffered by the plaintiff results from competition with an independently created work rather than from exploitation of plaintiff's own copyrighted material.

Having declined the opportumity to decide the case under traditional copyright principles, the court invoked the first annendment directly. Since the Supreine Court clearly had establishcd that commercial speech is within the sphere of first ainendinent protection, ${ }^{109}$ the court concluded that it constitutionally could not employ the Copyright Act to enjoin the defendant's comparative advertising: "When the Copyright Act and tlie First Amendinent both seek the same objective, their future coexistence is easily assured. However, when they operate at cross-purposes, the primacy of the First Amendment mandates that the Copyright Act be deprived of effectuation." 110 This direct constitutional appeal im Triangle Publications was unnecessary. Even if the exercise of defendant's first amendinent rights required the appropriation of plaintiff's expression-here the actual display of the copyrighted inagazine - this interest can be adequately protected without relying on the first amendment. Since the use itself does not reduce the value of plaintiff's copyright, the court could have invoked the fair use doctrine to permit the necessary use of expression. Nevertheless, the decision imdicates a judicial recognition of the necessity in some instances of resorting to an independent first amendment privilege to reconcile property rights in expression with principles of free speech. There reinains the problem of deciding when such resort in fact is constitutionally required.

\section{Locating the Boundaries}

\section{Necessity}

To state the obvious, a first amendment privilege to use copyrighted material is required only when the imternal mechanisms of substantive copyright law fail to perimit a necessary use of copyrighted expression. The scope of the first amendment privilege must provide

109. See, e.g., Bates v. State Bar of Arizona, 433 U.S. 350 (1977).

110. 445 F. Supp. at 882 . 
sufficient access to expression to insure meaningful freedom of speech. In a small number of situations, no amount of creativity or exertion on the part of a speaker can substitute for the duphcation of the particular expression of another. The reproduction of even copyrighted expression must be permitted where necessary to enable the speaker effectively to mject his or her own ideas into the public dialogue.

The reproduction of the frames from the Zapruder film in the Bernard Geis case is one such situation. The defendant had a first amendinent right to express his views on the Warren Commission Report. Since both the Commission and defendant relied extensively on the film in formulating their theories, denying defendant the right to reproduce essential portions would have effectively denied him the right accurately to offer his ideas to the public. Restrictimg him to an explanation of what the particular frames portrayed therefore would be in essence an abridgement of his constitutional right of free speech.

Perhaps because of the appealing factual setting of the Bernard Geis case, news photographs have provided the primary focus for attempts to describe the himits of a first amendment privilege. ${ }^{111}$ There may indeed be no stronger case for constitutionally required access than that involving a visual record of historic events. The Ninth Circuit has asserted that first amendment protection should not extend to nongraphic works: "Because there are available alternatives in the form of expressimg any verbal ideas, first amendment considerations should not himit copyright protection in this area."112 This position reveals a basic misunderstanding of the function of the first amendment privilege. That the ideas contained in a copyrighted work can be expressed in alternative forms simply ensures access to the ideas themselves. The purpose of the first amendment privilege, however, is to ensure access to expression when it too is needed for a meaningful public dialogue.

A recent Second Circuit case presents a situation that may require a first amendment privilege of access to copyrighted literary expression, as opposed to graphic expression. In Meeropol v. Nizer, ${ }^{113}$ the children of Julius and Ethel Rosenberg sought to prevent publication of The Implosion Conspiracy, a popular account by defendant of the espionage

111. Nimmer, supra note 38, at 1197-1200. Professor Nimmer gives as an example the photographs of the My Lai massacre. See Sid \& Marty Krofft Television Prods., Inc. v. McDonald's Corp., 562 F.2d 1157, 1171 (9th Cir. 1977).

112. Sid \& Marty Krofft Television Prods., Inc. v. McDonald's Corp., 562 F.2d 1157, 1171 n.17 (9th Cir. 1977).

113. For the complete history of the hitigation, see Meeropol v. Nizer, 361 F. Supp. 1063 (S.D.N.Y. 1973), affd, 505 F.2d 232 (2d Cir. 1974); 381 F. Supp. 29 (S.D.N.Y. 1974), affd, 560 F.2d 1061 (2d Cir. 1977); 417 F. Supp. 1201 (S.D.N.Y. 1976), rev'd, 560 F.2d 1061 (2d Cir. 1977), cert. denied, 434 U.S. 1013 (1978). 
trial of their parents. The book contained portions of letters written by the Rosenbergs while awaiting execution. The action was based in part on allegations of copyright infringement through Nizer's use of 1,957 words froin twenty-eight letters im which the plaintiffs claimed copyright. The letters originally had appeared in the Death House Letters of Ethel and Julius Rosenberg, which had been out of print for nearly twenty years. The portions of the letters used by Nizer constituted about $2.4 \%$ of the Death House Letters and less than $1 \%$ of The Implosion Conspiracy. The letters were used to illustrate the impact of the trial on the Rosenbergs and their feelings regarding the various appeals and petitions taken on their behalf. ${ }^{114}$ The district court denied a preliminary injunction against publication on the basis of Nizer's fair use defense, ${ }^{115}$ and eventually granted summary judgment to defendant on the infringement issue. ${ }^{116}$

The court clearly recognized the importance of borrowing the copyrighted expression:

It is not sufficient, as plaintiffs suggest, for the defendants who wished to describe the Rosenbergs' thoughts and feelings to resort to "the obvious device of not quoting thein directly." To do so would have prevented them from fully and accurately conveying the Rosenbergs' own expression, which in this situation may be essential to an accurate rendition of the relevant thoughts themselves. Furthermore, the Rosenbergs' expression itself inay be a relevant part of the history relating to the case. ${ }^{117}$

The court was answering precisely the right question: Can the right to free speech be adequately protected by free access to ideas, or do special circumstances require the freedom to use expression as well? The opinion also shows an appreciation of the distimction between reproducing the expression of another for the sake of exploitation and using the expression for the purpose of conveymg the defendant's own thoughts. The court found that Nizer was using the letters not to capitalize on the intellectual product of the Rosenbergs but to present effectively the facts relevant to his book. Therefore, even though the court assuned that publication of the book would diminish the commercial value of plaintiffs' copyrights, it granted defendant's motion for suinmary judgment. ${ }^{118}$

114. 417 F. Supp. 1201, 1212 (S.D.N.Y. 1976).

115. 361 F. Supp. 1063 (S.D.N.Y. 1973) (Tyler J.).

116. 417 F. Supp. 1201 (S.D.N.Y. 1976) (Gagliardi, J.).

117. Id. at 1212 (footnotes omitted).

118. The district court may have been influenced in part by concern over the plaintiffs' motives in the hitigation. The plaintiffs obviously were unhappy about the contents of Nizer's book, which implicitly concluded that the Rosenberg trial was not unfair. $417 \mathrm{~F}$. Supp. at 1208. In addition to the copyriglt infringement claim, the plaintiffs' complaint alleged defamation and invasion of privacy. $361 \mathrm{~F}$. Supp. at 1065. The district court noted the danger that copyright 
The Second Circuit reversed, holding that factual disputes as to the purpose of the use and its economic impact prevented summary disposition of the fair use claim. ${ }^{119}$ The court's concern with the potential economic impact of the use is consistent with the fundamental rationale of the fair use doctrine. The doctrine permits reasonable uses that do not seriously threaten the incentive structure of the copyright system. The Second Circuit noted that the mere fact that the letters had been out of print for twenty years did not necessarily indicate that they had no financial value. The market for republication or even novie rights might conceivably be affected by Nizer's use. If the plaintiffs could establish that there was significant harnn to the value of their copyrights, the fair use doctrine should not be applied to permit the use.

Assume Nizer can show that he used the Rosenbergs' letters not simply to exploit their market value but to enable him to deinonstrate his own conclusions regarding the case. Surely Nizer's right to speak (and the corresponding public right to hear) cannot be allowed to depend upon the sum Twentieth Century Fox may now be willing to offer plaintiffs for the movie rights to the letters. Fair use may not apply, but the first amendment does. The case may well justify a separate first amendment privilege for the use of copyrighted hiterary expression, just as the Bernard Geis case inay justify such a privilege for graphic expression. ${ }^{120}$

Free speech considerations should operate to permit the use of expression only to the extent necessary to allow the users to make their own contributions to the marketplace of ideas. Any additional license would undercut copyright incentives without advancing the objectives

might be used to suppress unfavorable information rather than for the legitimate purpose of protecting the proprietary interest in intellectual property, although it did not feel that this factor was of particular importance in the present case. $417 \mathrm{~F}$. Supp. at $1214 \mathrm{n} .11$.

Similar motives may have been present in the Rosemont case. See text accompanying notes 64-66 supra. The Rosemont corporation, which unsuccessfully attempted to enjoin the publication of the Random House biography of Howard Hughes, was apparently under the control of Hughes himself and was incorporated only a short time after he learned of the Random House project. 366 F.2d 303, 312 (2d Cir. 1966) (concurring opimion), cert. denied, 385 U.S. 1009 (1967). The Look copyrights, on which the action was based, were purchased from the magazine only after it refused to indicate whether it would itself take action against Randoun House. It thus seems clear that Roseinont was more concerned with suppressing information about Hughes than with protecting the value of its newly acquired copyrights. This factor may explam the hiberal application of the fair use doctrine in the Rosemont case. See id. at 311-13 (concurring opinion).

If it appears that the copyright owner is attempting to stifle public debate or channel it in a more favorable direction, free speech interests must be jealously guarded. When the plaintiff is attempting to control public discussion rather than to safeguard the economic value of the property, the courts should be generous in deciding whether the use is necessary to afford the defendant a meaningful opportunity to convey his ideas.

119. 560 F.2d 1061 (2d Cir, 1977), cert. denied, 434 U.S. 1013 (1978).

120. But see $1 \mathrm{M}$. NiMmer, supra note 39 , $\S 1.10[\mathrm{D}]$ n.82. 
of the first amendment. This necessity test should exclude the defendant who is merely attempting to exploit market demand for the plaimtiff's expression. The first amendment need not protect publication of a book containing the Zapruder frames for the simple purpose of selling the pictures to the public, for example. Nor should the result be different if the exploitation is of hiterary expression. There is little first amendment benefit in merely repackaging another's work.

The distimction between exploitation and legitimate necessity in the use of copyrighted expression is difficult to make. Commercial success should not be the touchstone because even a legitimate use that is necessary to facilitate free speech may benefit the user financially. It hardly seeins appropriate to rescind the first amendment privilege to use copyrighted material if the public becomes sufficiently interested in the secondary use to make the work a commercial success. If use of the Zapruder frames or the Rosenberg letters is necessary im order to insure the authors an opportunity to present their opimions, it should make no difference low briskly sales of Six Seconds in Dallas or The Implosion Conspiracy proceed. The coininercial success may be due to the author's own contribution rather than to public deinand for the appropriated expression. On the other hand, some inevitably will be tempted to seek success through the simple expedient of selling the property of another under the guise of free speech. If the defendant does not need to use the copyrighted material to make the desired poimt, or if in fact he has no point at all other than selling the appropriated expression, the court should not hesitate to find infringement. That the public purchases the work primarily for the appropriated material is certainly relevant in determining the character of the use, ${ }^{121}$ but it should not be decisive. If the necessity for the use is otherwise established, the motives of the public in buying the work should not preempt the author's right to present his own ideas. ${ }^{122}$

The recent case of Wainwright Securities, Inc. v. Wall Street Tran-

121. See Meeropol v. Nizer, 560 F.2d 1061, 1071 n.14 (2d Cir. 1977), cert. denied, 434 U.S. 1013 (1978); Time, Inc. v. Bernard Geis Assocs., 293 F. Supp. 130, 146 (S.D.N.Y. 1968).

122. As indicated in the text, the fact that the appropriated material contributes to the financial success of defendant's work should not be sufficient to justify the issuance of an injunction if the use is indeed required for a satisfactory expression of the user's ideas. The concept of a compulsory license has been suggested as one means of reconciling the conflicting imterests. Nimmer, supra note 38, at 1199-1200. As a general principle this approach is unacceptable, smce it would require that the defendant purchase his right to speak from the copyright owner-a result hardly in keeping with the concept of "free" speech. See Rosenfield, supra note 85, at 803. But see Italian Book Corp. v. American Broadcasting Co., Inc., 458 F. Supp. 65, 71 n.14 (S.D.N.Y. 1978). When the defendant in fact is receiving an economic benefit from the use, however, it would not appear to be inconsistent with first amendment principles to require that he return to the copyright owner that portion of the profits attributable to the use of the copyrighted material. 
script Corp. ${ }^{123}$ focuses on the problem of differentiating between free speech and commercial exploitation. A short time before it reversed the grant of summary judgment in the Nizer case, the Second Circuit was asked to review a preliminary injunction prohibiting a weekly financial newspaper from publishing abstracts of copyrighted research reports. The plaintiff was a brokerage firm that specialized in the preparation and sale of analytical reports examining the financial prospects of inajor corporations. The reports, which included the analyst's predictions and conclusions, at times required several inonths to prepare and were up to forty pages in length. They were distributed to major banks, insurance coinpanies, and mutual funds. Defendant's newspaper regularly featured abstracts of plaintiff's reports. In defending against the claim of copyright infringement, the defendant raised both the fair use doctrine and the first amendment. As to the latter, the defendant argued that its publication of the abstracts was constitutionally protected reporting of financial news. The district court saw no need to address the first amendment issue separately, since in its view the scope of the fair use doctrine was broad enough to avoid conflict between copyright law and free speech. ${ }^{124}$ It granted a preliminary injunction and disimissed the fair use defense on the ground that the use materially affected the value of plaintiff's copyrights. The Second Circuit affirmed, specifically rejecting both the fair use and first amendment arguments of the defendant.

News events as such are clearly unsuitable for copyright protection. The idea-expression dichotomy denies copyright protection to the substance of the news even though "the particular forin or collocation of words in which the writer has communicated it" inay be copyrighted. ${ }^{125}$ Subsequent reporting of the facts contained in a news story thus would not constitute copyright infringement, provided the actual expression was not appropriated. ${ }^{126}$ A distinct problem arises, however, when the news event is itself a forin of expression, such as a pubhic speech or the issuance of a report. The reporting of events such as these nnay well require some use of the expression that is the essence of

123. 558 F.2d 91 (2d Cir. 1977), cert. denied, 434 U.S. 1013 (1978).

124. 418 F. Supp. 620, 624 (S.D.N.Y. 1976).

125. International News Servs. v. Associated Press, 248 U.S. 215, 234 (1918).

126. Although not amounting to copyright infringement, the consistent appropriation of facts from competing news sources may give rise to a cause of action in tort for "misappropriation." Id. at 541-42; H.R. REP. No. 94-1476, supra note 4, at 132; S. REP. No. 94-473, supra note 4, at 116. For a time, the constitutionality of the misappropriation doctrine was in question. See Sears, Roebuck \& Co. v. Stiffel Co., 376 U.S. 225 (1964); Compco Corp. v. Day-Brite Lighting, Inc., 376 U.S. 234 (1964). The doubt has since largely been removed. See Goldstein v. California, 412 U.S. 546 (1973); 17 U.S.C. app. $\$ 301$ (1976). Since the copyright claim in Wainwright was upheld, there was no need for the court to examine this alternative. 
the event. ${ }^{127}$ The Copyright Act specifically recognizes news reporting as one of the traditional forms of fair use. ${ }^{128}$ In any proper application of the fair use doctrine, however, the financial impact of the use inust be considered. Uses in cormection with news reporting generally will have little adverse econormic effect, in part because they frequently present the work in impermanent and incomplete form. But when the financial impact is indeed substantial, traditional fair use doctrine may be unable to accommodate the appropriation. In such cases the court inust decide whether first amendment protection of news reporting nevertheless precludes liability. Surely in some circumstances " $[t]$ he public interest in the news value of the author's work inay cut across or postpone his rights."129 This is in fact the substance of the Bernard Geis holding. Wainwright, however, does not present such a situation.

The event that the defendant was reporting was the issuance of the plaintiffs financial reports. The reports certainly could be regarded as news and were in fact soinetimes notcd in the Wall Street Journal. Since the news event was itself a form of expression, one certainly could argue that soine use of the expression contained in the reports was necessary to describe the event to the public. ${ }^{130}$ The court apparently conceded as inuch by implicitly approving the Wall Street Journal's coverage of the reports despite the Journal's use of significant portions of plaintiff's expression. ${ }^{131}$ Why should the court treat the defendant's use less favorably? The answer lies in the distinction between exploitation and necessity in the use of copyrighted expression. Although the defendant had a first ainendment right to report on the issuance of the copyrighted inaterial and to present its own views on the event to the public, it inade significantly greater use of plaintiff's expression than was necessary to accomplish either of those goals. ${ }^{132}$ The defendant in fact made no attempt to contribute any ideas of its own to the public dialogue, and it appropriated so much of the copyrighted expression as in effect to be selling rather than reporting on the plaintiff's work. ${ }^{133}$ The defendant's own advertising expressly portrayed the

127. See Public Affairs Assocs., Inc. v. Rickover, 284 F.2d 262, 272-73 (D.C. Cir. 1960) (dissenting opinion), vacated for insufficient record, 369 U.S. 111 (1962); B. KAPLAN, supra note 11, at 61.

128. 17 U.S.C. app. $\$ 107$ (1976).

129. B. KAPLAN, supra note 11 , at 273.

130. This is particularly true since the protected "expression" includes more than the literal words and extends to the basic pattern of the work, including the selection and arrangement of facts. 1 M. Nimmer, supra note $39, \S 2.11$.

131. 558 F.2d at 95 n.2.

132. Id. at $96 \mathrm{n} .3$.

133. The issue is not unlike that presented in Zacchini v. Scripps-Howard Broadcasting Co., 433 U.S. 562 (1977). The Supreme Court's opinion in that case indicated that the plaintiffs right of publicity under the applicable state law could not prevent the reporting of the facts surrounding 
publication as offering condensed versions of reports from institutional research firns. ${ }^{134}$ In other words, it was offering for sale abridged versions of copyriglited works-a right expressly reserved by statute to the copyright liolder. ${ }^{135}$ Defendant's use of the copyrighted expression was not necessary for the exercise of its legitimate right of free speech. It was merely an exploitation of the talent and efforts of others.

\section{Public Interest}

In attempting to define the scope of the first annendment privilege, this discussion has focused on the necessity of using copyrighted expression without regard to the nature of the user's topic. Yet when the courts have invoked the fair use doctrine as a means of protecting first annendment interests, they generally have chosen to frame the issue in terms of the public interest in an unrestricted discussion of the particular subject. ${ }^{136}$ Should the constitutional limitations on copyright protection vary according to the "newsworthiness" of the topic or the value of the user's contribution? If the use is in fact necessary for the adequate expression of the user's ideas, any attempt to limit the privilege to speech concerning "news" would be inconsistent with the acknowledged breadth of free speech protection. ${ }^{137}$

There is obvious danger in making the scope of first amendment privilege dependent on the outcome of a judicial inquiry into the importance of the topic. ${ }^{138}$ The Supreme Court itself has grappled with this problein in defining the scope of a first amendment privilege in the area of libel law. A plurality of the Court in Rosenbloom v. Me-

Zacchini's act. But the Court held that the constitutional immunity did not extend to the broadcasting of the entire performance. Id. at 574-75. See text accompanying notes 29-36 supra.

134. 418 F. Supp. at 622.

135. 17 U.S.C. app. $§ 106(2)$ (1976).

136. The Bernard Geis result, for example, rested on "a public interest in having the fullest information available on the nurder of President Kennedy." 293 F. Supp. at 146. In vacating the injunction restraining the distribution of the Howard Hughes biography in Rosemont, the Court referred to the public interest in having an opportunity to become acquainted with a person of his unique talents and contributions. 366 F.2d at 309. Similarly, in denying a preliminary injunction in Nizer, Judge Tyler noted the "continumg interest in and importance of the celebrated Rosenberg case" and observed that "this very court liouse is adjacent to Foley Square where earlier this month, and in June of other years, demonstrations took place in nemory of the Rosenbergs and their execution." 361 F. Supp. at 1068.

137. "Freedoin of discussion, if it would fulfill its historic function in this nation, inust embrace all issues about which information is needed or appropriate to enable the members of society to cope with the exigencies of their period." Thornhill v. Alabama, 310 U.S. 88, 102 (1940). See Meiklejohn, supra note 20, at 256-57.

138. In commenting on constitutional privilege and the right of privacy, Professor Emerson las written: "a classification that bases the right to First Amendment protection on some estimate of how much general interest there is in the communication is surely in conflict with the whole idea of the First Amendment." T. EMERSON, THE SySTEM OF FREEDOM OF EXPRESSION 554 (1970). 
tromedia, Inc., ${ }^{139}$ chose to extend the first amendment privilege that was announced in New York Times v. Sullivan Co. ${ }^{140}$ to "all discussion and communication involving matters of public or general concern."141 Justice Marshall, in dissent, commented upon the hazards of such an approach:

Courts, including this one, are not anointed with any extraordinary prescience . . . . [C]ourts will be required to somehow pass on the legitimacy of interest in a particular event or subject; what information is relevant to self-government. . . . The danger such a doctrine portends for freedom of the press seems apparent. ${ }^{142}$

Justice Marsliall also recognized the substantial uncertainty resulting froin the adoption of this ad hoc test. ${ }^{143}$ His position ultinnately prevailed wlien the Court abandoned the Rosenbloom formulation in Gertz v. Robert Welch, Inc. ${ }^{144}$

The dangers involved in having courts weigh the importance of the topic are only inagnified when the courts attempt to evaluate the quality of a defendant's contribution. Yet the court in Bernard Geis felt coinpelled to state that the defendant "did serious work on the subject and has a theory entitled to public consideration." 145 In denying a preliminary injunction against publication of The Implosion Conspiracy, the district court in Nizer predicted that "defendants are likely to prove that their book is a serious, full and readable account of what was a trial of great historical interest."146 Similarly, the Rosemont opinion suggests that the fair use doctrime protects only works that offer some value or benefit to the public. ${ }^{147}$

If the inquiry into the inerits of a defendant's work is limited to distinguishing the use of copyrighted material to express the author's own ideas froin the inere exploitation of the work of another, the problem is simply one of terminology. But if the test is in fact meant to focus not on the necessity for the use, but on the merits of defendant's output, it is indeed troublesome. It would be difficult to articulate any acceptable standard for judging whether a particular work was sufficiently serious or valuable to justify a first amendınent privilege. ${ }^{148}$ In-

139. 403 U.S. 29 (1971).

140. 376 U.S. 254 (1964). See text accompanying notes $24-26$ supra.

141. 403 U.S. at 44 (1971).

142. Id. at 79 (Marshall, J., dissenting) (citations omitted).

143. Id. at 81 (Marshall, J., dissentimg).

144. 418 U.S. 323,346 (1974).

145. 293 F. Supp. at 146.

146. 361 F. Supp. at 1068.

147. 366 F.2d at 307. The court in Triangle Publications analyzed the defendant's use of the $T V$ Guide cover in a similar inanner. "Such comparative advertising, when undertaken in the serious unanner that defendant did herem, represents an important source of information for the education of consunners in a free enterprise system." $445 \mathrm{~F}$. Supp. at 883.

148. Nizer demonstrates the enormous practical problems of such an approach. The plaintiffs 
deed, the minimal originahity and creativity standards for extending copyright protection can be seen as an attempt to elimmate the need for such determinations of merit or value. ${ }^{149}$ Furthermore, judgments as to the merits of a work should properly be left to the public. ${ }^{150}$

It is doubtful that any doctrinal formulation of the first amendment privilege actually could eliminate the influence of judicial perceptions of the merit or importance of the defendant's work. Much of copyright law rests on ephemeral distinctions and categories that imvite flexible interpretation on a case-by-case basis. In analyzing the first amendment issue, the court first must determine whether any protected expression in fact has been appropriated. If so, the court then inust consider whether the use was necessary. If a sufficient degree of necessity is established, the extent of the permissible use must be determined. In fixing each of these lines, the courts undoubtedly will contmue to be influenced by their perceptions of the value and significance of the defendant's work. As long as the primary focus remains on the necessity for the use, little harn is likely to result. But such factors as the public interest in the subject inatter or the public benefit derived from defendant's contribution should not be elevated to independent significance. If this occurs, there is a risk that free speech interests may be subtly undermined by notions of relevance or propriety.

\section{CONCLUSION}

A legal system that simultaneously recognizes both a basic right of free speech and proprietary interests in forms of expression should be prepared to resolve inevitable conflicts. Direct appeals to constitutional principles are appearing ever more frequently in copyright litigation. The Supreme Court has not yet attempted to reconcile the conflict between copyright law and free speech, although it has addressed analogous conflicts in such cases as New York Times Co. v. Sullivan, Time, Inc. v. Hill, and Zacchini v. Scripps-Howard Broadcasting Co.

This imcreasing recognition of first aunendment interests need not alann those dedicated to a strong and efficient copyright system. Copy-

submitted fourteen affidavits from history professors and authors in an attempt to show that The Implosion Conspiracy was "riddled with distortions and inaccuracies and thus has no historical value." 417 F. Supp. at 1208 . The district court refused to be led into such an inquiry, but it did state that in order for a historical work to be protected under the fair use doctrine there must be "some serious attempt to describe a historical event which could be of some benefit to the public at large." Id. at 1209.

149. See $1 \mathrm{M}$. NIMMER, supra note $39, \S 2.01$. Similarly, in determining copyrightability, the courts generally will not consider the truth or falsity, nor the soundness or unsoundness, of the views contained in the work. Id. $\$ 2.17$.

150. Paulsen v. Personality Posters, Inc., 59 Misc. 2d 444, 449-50, 299 N.Y.S.2d 501, 507-08 (Sup. Ct. 1968). 
right law, by taking care to distinguish between idea and expression, long has respected the values inherent in the first amendment. The confrontation with freedoin of speech therefore is not severe. Many of the remaining conflicts can be resolved by means of traditional fair use concepts. But if the fair use doctrine is left to carry the constitutional burden unaided, it will become disfigured and eventually cease to perform effectively its traditional function.

The ultimate response to the confrontation between free speech and copyright should be the recognition of an independent first amendment privilege. But the copyright system-itself an effort to implement the constitutionally sanctioned aim of encouraging creative activityshould not be undermined needlessly. The necessity for appropriation therefore inust be examined carefully in each imdividual case to identify those situations im which the user cannot adequately exercise the right of free speech without at least limited access to copyrighted expression. When traditional copyright doctrimes do not permit such access, a first amendment privilege should be recognized to the extent necessary to enable potential users to contribute their ideas effectively to the public dialogue. The recognition of this rather narrow yet significant first amendment privilege will safeguard not only freedom of speech, but the integrity of the copyright system as well. 